\title{
Intravenous administration of ghrelin stimulates growth hormone secretion in vagotomized patients as well as normal subjects
}

\author{
Ryoko Takeno $^{1}$, Yasuhiko Okimura ${ }^{2}$, Genzo Iguchi $^{1}$, Masahiko Kishimoto ${ }^{1}$, Takumi Kudo ${ }^{1}$, Kentaro Takahashi ${ }^{1}$, \\ Yutaka Takahashi ${ }^{1}$, Hidesuke Kaji ${ }^{3}$, Masakazu Ohno ${ }^{4}$, Hajime Ikuta ${ }^{4}$, Yoshikazu Kuroda ${ }^{4}$, Tetsuji Obara ${ }^{5}$, \\ Hiroshi Hosoda $^{6}$, Kenji Kangawa ${ }^{6}$ and Kazuo Chihara ${ }^{1}$ \\ ${ }^{1}$ Division of Endocrinology/Metabolism, Neurology and Hematology/Oncology, Department of Clinical Molecular Medicine and ${ }^{4}$ Division of \\ Gastroenterological Surgery, Kobe University Graduate School of Medicine, Hyogo, 650-0017, Japan, ${ }^{2}$ Department of Basic Allied Medicine, Kobe \\ University School of Medicine, Kobe, 654-0142, ${ }^{3}$ College of Nursing Art and Science, Hyogo, 673-8588, ${ }^{5}$ Obara Hospital, Hyogo, 654-0121 and \\ ${ }^{6}$ Department of Biochemistry, National Cardiovascular Center, Research Institute, Osaka, 565-8565, Japan
}

(Correspondence should be addressed to Yasuhiko Okimura, Department of Basic Allied Medicine, Kobe University School of Medicine, 7-10-2, Tomogaoka, Suma-ku, Kobe, 654-0142, Japan; Email: okimura@ams.kobe-u.ac.jp)

\begin{abstract}
Objective: Ghrelin is a potent peptide stimulating GH secretion. Besides its direct action on the pituitary, ghrelin has been reported to stimulate GH release via the vagal afferent nerve in rats. To examine the involvement of vagal nerve in ghrelin-induced GH secretion in humans, GH responses to ghrelin were compared between vagotomized patients with gastrectomy and normal subjects. Methods: Ghrelin $(0.2 \mu \mathrm{g} / \mathrm{kg})$ or GHRH $(1 \mu \mathrm{g} / \mathrm{kg})$ was administered intravenously in vagotomized patients and normal subjects on separate days, and plasma GH responses to the stimuli were examined.

Results: Ghrelin caused a significant plasma GH rise in both vagotomized patients and normal subjects. Peak GH levels in vagotomized patients $(37.5 \pm 16.9 \mathrm{ng} / \mathrm{ml})$ were not different from those in normal subjects $(29.9 \pm 23.1 \mathrm{ng} / \mathrm{ml})$. The areas under the curve of GH response to ghrelin did not differ between the two groups. GHRH also increased GH levels, and peak GH levels and areas under the curve after GHRH stimulation were also comparable between vagotomized patients and normal subjects.

Conclusions: In the present study, the involvement of the afferent vagal nerve in ghrelin-induced GH secretion was not confirmed in humans.
\end{abstract}

European Journal of Endocrinology 151 447-450

\section{Introduction}

Growth hormone (GH) secretion is governed by two hypothalamic hormones, growth hormone-releasing hormone $(\mathrm{GHRH})$ and somatostatin. GHRH stimulates the secretion of GH while somatostatin inhibits it (1). In addition to GHRH, another GH-releasing peptide, ghrelin, has been identified (2). Ghrelin is a natural ligand for the receptors for $\mathrm{GH}$ secretagogues, synthetic compounds with GH-releasing activity (3). Ghrelin stimulates GH secretion from cultured rat pituitary cells (2), and intravenously administered ghrelin increases plasma GH levels in humans $(4-6)$ and rats $(2,7)$. In addition, ghrelin stimulates food intake when administered intraventricularly or intravenously $(8,9)$. Ghrelin is detected in peripheral blood, and the main source of circulating ghrelin appears to be the stomach since resection of stomach was found to decrease plasma ghrelin levels (10). However, circulating ghrelin is unlikely to play a role in regulating $\mathrm{GH}$ secretion since pulsatile GH secretion was preserved in freely moving rats treated with GH secretagogue blocker (11). On the other hand, gastric afferent vagal nerve has been reported to be involved in stimulatory effects of ghrelin on GH secretion and food intake in rats $(9,12)$. These findings led us to compare the $\mathrm{GH}$ responses to ghrelin injections in patients with vagotomy and normal healthy subjects.

\section{Materials and methods}

\section{Subjects}

Six vagotomized patients associated with gastrectomy and six healthy volunteers were studied. Four patients have undergone total gastrectomy and two patients have undergone partial gastrectomy, with the fundus of the stomach remaining, as a result of stomach cancer and have no recurrence. All the patients have undergone truncal vagotomy and have no recurrence. Clinical characteristics of participants were summarized in Table 1. All subjects gave their written informed 
Table 1 Clinical characteristics of six patients with vagotomy associated with gastrectomy and six normal subjects. All values are mean \pm S.D.

\begin{tabular}{lccc}
\hline & Vagotomized patients & Normal subjects & $P$ value \\
\hline Number & 6 & 6 & N.D. \\
Age (years) & $56.8 \pm 14.4$ & $33.8 \pm 7.9$ & $P<0.05$ \\
Sex (female/male) & $2 / 4$ & $1 / 5$ & N.D. \\
Body mass index $\left(\mathrm{kg} / \mathrm{m}^{2}\right)$ & $19.7 \pm 1.5$ & $21.7 \pm 4.3$ & $P=0.09$ \\
IGF-I (ng/ml) & $114 \pm 17.3$ & $218 \pm 59.1$ & $P<0.05$ \\
PG (mg/dl) & $87.8 \pm 11.5$ & $90.4 \pm 16.7$ & $P=0.495$ \\
Total ghrelin (fmol/ml) & $93.6 \pm 26.5$ & $280.9 \pm 120.7$ & $P<0.05$ \\
Period after gastrectomy (years) & $3.2 \pm 3.0$ & & \\
\hline
\end{tabular}

PG, plasma glucose. N.D., not different.

consent to participate in the study, which was approved by the Kobe University Ethical Committee.

\section{Ghrelin test and GHRH test}

All vagotomized patients and normal subjects underwent a ghrelin test, and five vagotomized patients and six normal subjects underwent a GHRH test on separate days. After an overnight fast, at $0830-0900 \mathrm{~h}$ an indwelling catheter was placed into an antecubital vein of the forearm. Blood samples were obtained just before and 15, 30, 45, 60, 90 and $120 \mathrm{~min}$ after the bolus injection of human ghrelin $(0.2 \mu \mathrm{g} / \mathrm{kg}$ body weight) or human GHRH1-40 (1 $\mu \mathrm{g} / \mathrm{kg})$. Blood samples were centrifuged and the resulting plasma was stored at $-20{ }^{\circ} \mathrm{C}$ until assay. Plasma $\mathrm{GH}$ concentrations were determined by ELISA (Toso, Tokyo, Japan). The sensitivity of the assay was $0.15 \mathrm{ng} / \mathrm{ml}$. The inter- and intra-assay coefficients of variation were 2.9 and $2.4 \%$, respectively. The GH responses are expressed in absolute terms and as areas under curves (AUCs) calculated by trapezoidal integration. Plasma insulin-like growth factor (IGF)-I levels were determined by immunoradiometric assay (Daiichi Radio Isotope, Tokyo, Japan). The sensitivity of the assay was $4.2 \mathrm{ng} / \mathrm{ml}$. The inter- and intra-assay coefficients of variation were 3.0 and $3.5 \%$, respectively. Total plasma ghrelin levels were determined with RIA recognizing C-terminal ghrelin (13). Plasma glucose levels were measured by glucose oxidase colorimetric method (Sanwa Kagaku, Nagoya, Japan).

\section{Statistical analysis}

The statistical analysis was carried out using nonparametric ANOVA (Friedman test) and then Wilcoxon test, as appropriate. The results are expressed as mean \pm S.E.M. $P<0.05$ was considered significant.

\section{Results}

Intravenous administrations of ghrelin caused significant plasma GH rises with peak levels of $37.5 \pm 16.9$ and $29.9 \pm 23.1 \mathrm{ng} / \mathrm{ml}$ in vagotomized patients with gastrectomy and normal subjects, respectively. AUCs after ghrelin administration were 2037.1 \pm 938.0 and $1455.9 \pm 856.9 \mathrm{ng} / \mathrm{min}$ per $\mathrm{ml}$ in the patients and normal subjects, respectively. Peak GH levels and AUCs did not differ between two groups (Fig. 1). GHRH administration also elevated plasma GH levels with peak levels of $16.5 \pm 7.0$ and $9.4 \pm 1.8 \mathrm{ng} / \mathrm{ml}$ in

A

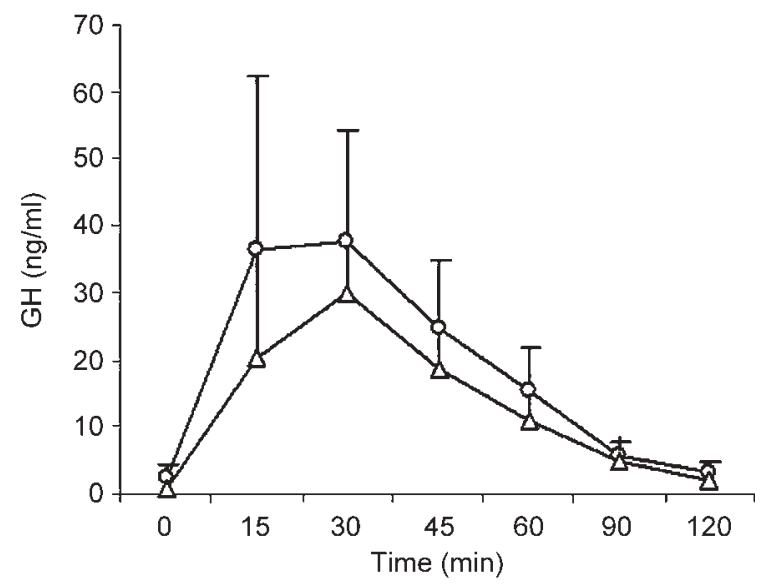

$B$
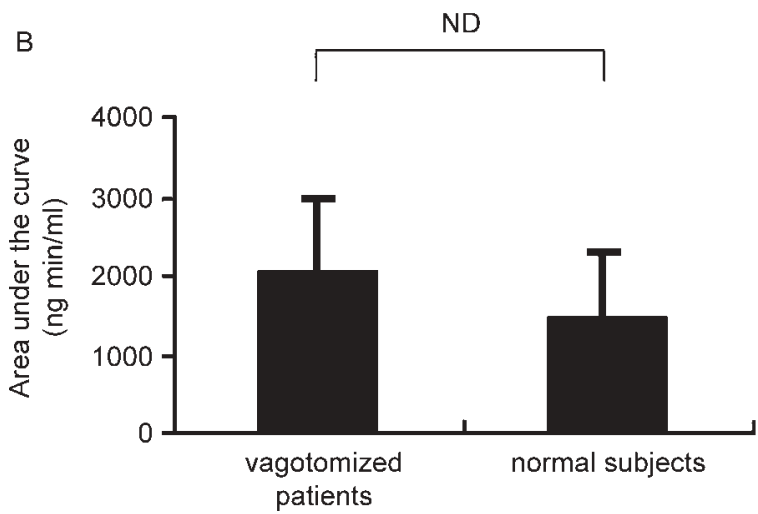

Figure $1 \mathrm{~A}$. Effect of intravenous administration of ghrelin $(0.2 \mu \mathrm{g} / \mathrm{kg}$ ) on plasma GH levels (mean \pm S.E.M.) in six vagotomized patients $O$ and six normal subjects $\triangle$. B. AUCs (mean \pm S.E.M.) in response to ghrelin are shown in vagotomized patients and normal subjects. 
vagotomized patients and normal subjects, respectively. AUCs after GHRH injection were 1210.0 1641.6 and $686.6 \pm 101.2 \mathrm{ng} / \mathrm{min}$ per $\mathrm{ml}$ in the patients and normal subjects, respectively. There was no difference in GHRH-induced GH response between vagotomized patients and normal subjects (Fig. 2). Peak GH levels to ghrelin were greater than those to GHRH in the vagotomized patients. Body mass index and fasting plasma glucose were not different in both groups, but plasma IGF-I and basal ghrelin levels were lower in the patients than in normal subjects (Table 1).

\section{Discussion}

Asakawa et al. (9) have reported that ghrelin exhibited potent orexigenic effects which is lost after vagotomy in rats. In addition, Date et al. (12) have shown that $\mathrm{GH}$ responses to ghrelin were attenuated in vagotomized rats compared with control rats. Also, they have shown the presence of ghrelin receptor in vagal afferent nerve and the attenuation of ghrelin-induced c-Fos expression in neuropeptide Y-producing and

A

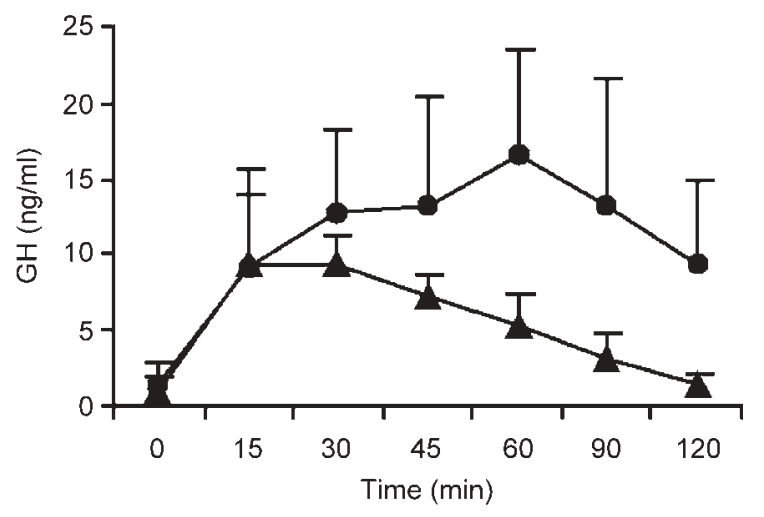

B

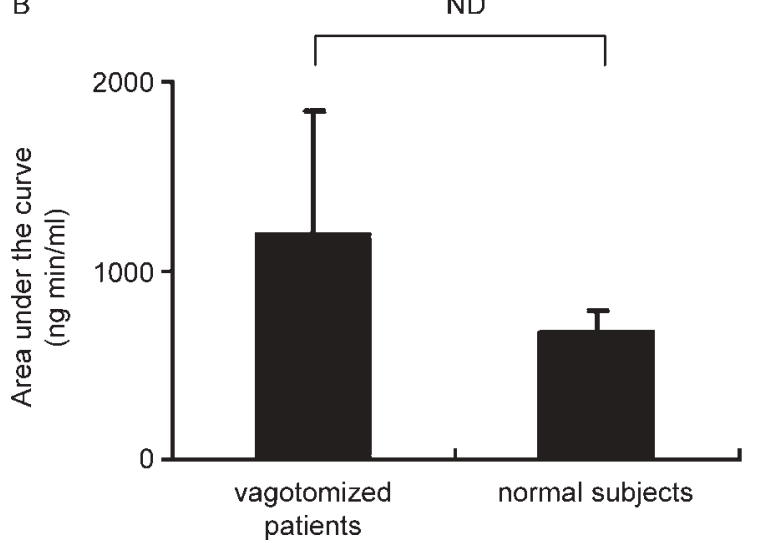

Figure $2 \mathrm{~A}$. Effect of intravenous administration of GHRH $(1 \mu \mathrm{g} / \mathrm{kg})$ on plasma GH levels (mean \pm S.E.M. $)$ in six vagotomized patients and six normal subjects $\mathbf{\Lambda}$. B. AUCs (mean \pm S.E.M.) in response to GHRH are shown in vagotomized patients and normal subjects.
GHRH-producing neurons in the hypothalamus of vagotomized rats. Furthermore, Sakata et al. (14) reported recently, having used retrograde tracing with fluorogold, that some cells containing ghrelin receptors in the nodose ganglion project to the stomach. These findings suggest a possible mechanism for ghrelin produced in the stomach to stimulate $\mathrm{GH}$ release and food intake via vagal afferent nerves in rats. In agreement with these results that the central nervous system, at least in part, is involved in ghrelin action, Popovic et al. (15) have reported that the main action of ghrelin to stimulate GH release is exerted at the hypothalamic level.

In contrast, in the present study, intravenous administration of ghrelin resulted in a marked GH release in both vagotomized patients and normal subjects to a similar extent, and GH secretion to ghrelin was greater than to GHRH. These findings suggest no involvement of the vagal nerve in ghrelin-induced GH secretion in humans.

Although the reason why GH secretions in response to ghrelin differed between humans and rats is unclear, several possibilities may explain it. One possibility is a modulation of GH response by IGF-I. It is well known that IGF-I has an inhibitory action on pulsatile and provocation-induced GH secretions in humans $(16,17)$. Since plasma IGF-I levels in the patients with vagotomy were lower than those in normal subjects, it may be responsible for the augmentation of $\mathrm{GH}$ response to ghrelin in vagotomized patients. However, not all the provocative tests were influenced by IGF-I. For example, IGF-I is unlikely to reduce GH responses to arginine. A s.c. administration of IGF-I does not suppress GH response to i.v. infusion of arginine (18). Thus, it is unclear that IGF-I, in fact, suppresses GH release to ghrelin, although the possibility that IGF-I modulates $\mathrm{GH}$ response to ghrelin cannot be excluded.

The difference in mean age between the vagotomized patients and normal subjects may have affected $\mathrm{GH}$ responses. In general, GH responses to provocative stimuli are decreased in the elderly. Broglio et al. (19) have reported the attenuated $\mathrm{GH}$ secretion to ghrelin in elderly people. Hence, the GH response to ghrelin in the vagotomized patients may be underestimated but not overestimated compared with normal subjects since the vagotomized patients were older than normal subjects. Therefore, it is unlikely that the attenuated responses to ghrelin, which should have been observed in vagotomized patients as well as vagotomized rats, were masked in the vagotomized patients because of their age.

Gastrectomy itself may influence GH secretion induced by ghrelin in humans. In rats, however, resection of the gastrointestinal tract with vagotomy also leads to attenuated $\mathrm{GH}$ secretion to growth hormonereleasing peptide-6 (GHRP-6), one of the GH secretagoues, which is comparable to the findings in rats with selective vagotomy (20). Therefore, gastrectomy itself 
does not appear to be a factor explaining the difference between humans and rats.

Gastrectomy causes a decrease in plasma ghrelin levels (10). In agreement with this previous finding, plasma total ghrelin levels were lower in the patients than in normal subjects in the present study, suggesting that additional sources of ghrelin production are not sufficient to maintain plasma ghrelin levels. It is difficult to exclude the possibility that low plasma ghrelin level may have affected the $\mathrm{GH}$ response to ghrelin.

The results of Date et al. (12) in rats would indirectly suggest that the low dose of ghrelin utilized in these vagotomized patients may in part be a reason for concluding that ghrelin administration did not release $\mathrm{GH}$ via the vagal nerve pathway. It is still unclear why the GH response to ghrelin differed between vagotomized humans and rats. However, intravenously administered ghrelin seems to stimulate $\mathrm{GH}$ release by its direct action on the hypothalamus/pituitary region rather than via vagal afferent nerve in humans, at least under the present experimental conditions.

In summary, intravenous administration of ghrelin caused marked GH response in patients with vagotomy as well as in normal subjects. Under the present experimental conditions, the involvement of the afferent vagal nerve in ghrelin-induced GH secretion was not confirmed in humans.

\section{Acknowledgements}

This study was supported in part by grants-in-aid from the Japanese Ministry of Education, Culture, Sports, Science and Technology, the Japanese Ministry of Health, Labor and Welfare and the Foundation for Growth Science.

\section{References}

1 Sato M, Chihara K, Kita T, Kashio Y, Okimura Y, Kitajima N \& Fujita T. Physiological role of somatostatin-mediated autofeedback regulation for growth hormone: importance of growth hormone in triggering somatostatin release during a trough period of pulsatile growth hormone release in conscious male rats. Neuroendocrinology 198950 139-151.

2 Kojima M, Hosoda H, Date Y, Nakazato M, Matsuo H \& Kangawa K. Ghrelin is a growth-hormone-releasing acylated peptide from stomach. Nature $1999 \mathbf{4 0 2} 656-660$.

3 Howard AD, Feighner SD, Cully DF, Arena JP, Liberator PA, Rosenblum CI et al. A receptor in pituitary and hypothalamus that functions in growth hormone release. Science $1996 \mathbf{2 7 3}$ 974-977.

4 Takaya K, Ariyasu H, Kanamoto N, Iwakura H, Yoshimoto A, Harada $\mathrm{M}$ et al. Ghrelin strongly stimulates growth hormone release in humans. Journal of Clinical Endocrinology and Metabolism $2000854908-4911$.

5 Arvat E, Maccario M, Di Vito L, Broglio F, Benso A, Gottero C et al. Endocrine activities of ghrelin, a natural growth hormone secretagogue (GHS), in humans: comparison and interactions with hexarelin, a nonnatural peptidyl GHS, and GH-releasing hormone. Journal of Clinical Endocrinology and Metabolism 2001 86 1169-1174.
6 Peino R, Baldelli R, Rodriguez-Garcia J, Rodriguez-Segade S, Kojima M, Kangawa K et al. Ghrelin-induced growth hormone secretion in humans. European Journal of Endocrinology 2000 $14311-14$

7 Tolle V, Zizzari P, Tomasetto C, Rio MC, Epelbaum J \& Bluet-Pajot MT. In vivo and in vitro effects of ghrelin/motilin-related peptide on growth hormone secretion in the rat. Neuroendocrinology $20017354-61$.

8 Wren AM, Small CJ, Ward HL, Murphy KG, Dakin CL, Taheri S et al. The novel hypothalamic peptide ghrelin stimulates food intake and growth hormone secretion. Endocrinology $2000 \mathbf{1 4 1}$ 4325-4328.

9 Asakawa A, Inui A, Kaga T, Yuzuriha H, Nagata T, Ueno N et al. Ghrelin is an appetite-stimulatory signal from stomach with structural resemblance to motilin. Gastroenterology $2001 \mathbf{1 2 0}$ 337-458.

10 Ariyasu H, Takaya K, Tagami T, Ogawa Y, Hosoda K, Akamizu T et al. Stomach is a major source of circulating ghrelin, and feeding state determines plasma ghrelin-like immunoreactivity levels in humans. Journal of Clinical Endocrinology and Metabolism 2001 $864753-4758$.

11 Okimura Y, Ukai K, Hosoda H, Murata M, Iguchi G, Iida K et al. The role of circulating ghrelin in growth hormone $(\mathrm{GH})$ secretion in freely moving male rats. Life Science 200372 2517-2524.

12 Date Y, Murakami N, Toshinai K, Matsukura S, Niijima A, Matsuo $\mathrm{H}$ et al. The role of the gastric afferent vagal nerve in ghelininduced feeding and growth hormone secretion in rats. Gastroenterology $2002 \mathbf{1 2 3} 1120-1128$.

13 Hosoda H, Kojima M, Matsuo H \& Kangawa K. Ghrelin and desacyl ghrelin: two major forms of rat ghrelin peptide in gastrointestinal tissue. Biochemical and Biophysical Research Communications 2000279 909-913.

14 Sakata I, Yamazaki M, Inoue K, Hayashi Y, Kangawa K \& Sakai T. Growth hormone secretagogue receptor expression in the cells of the stomach-projected afferent nerve in the rat nodose ganglion. Neuroscience Letters $2003 \mathbf{3 4 2} 183-186$.

15 Popovic V, Miljic D, Micic D, Damjanovic S, Arvat E, Ghigo E et al. Ghrelin main action on the regulation of growth hormone release is exerted at hypothalamic level. Journal of Clinical Endocrinology and Metabolism $2003 \mathbf{8 8} 3450-3453$.

16 Cauter EV, Caufriez A, Kerkhofs M, Onderbergen AV, Thorner MO \& Copinschi G. Sleep, awakenings, and insulin-like growth factor-I modulate the growth hormone $(\mathrm{GH})$ secretory response to GH-releasing hormone. Journal of Clinical Endocrinology and Metabolism $1992741451-1459$.

17 Hartman ML, Clayton PE, Johnson ML, Celniker A, Perlman AJ, Alberti KG \& Thorner MO. A low dose euglycemic infusion of recombinant human insulin-like growth factor I rapidly suppresses fasting-enhanced pulsatile growth hormone secretion in humans. Journal of Clinical Investigation 199391 2453-2462.

18 Gianotti L, Maccario M, Lanfranco F, Ramunni J, Di Vito L, Grottoli $\mathrm{S}$ et al. Arginine counteracts the inhibitory effect of recombinant human insulin-like growth factor I on the somatotroph responsiveness to growth hormone-releasing hormone in humans. Journal of Clinical Endocrinology and Metabolism 2000 $853604-3608$.

19 Broglio F, Benso A, Castiglioni C, Gottero C, Prodam F, Destefanis S et al. The endocrine response to ghrelin as a function of gender in humans in young and elderly subjects. Journal of Clinical Endocrinology and Metabolism $2003 \mathbf{8 8} 1537-1542$.

20 Ahnfelt-Ronne I, Nowak J \& Olsen UB. Do growth hormonereleasing peptides act as ghrelin secretagogues? Endocrine 2001 $14133-135$.

Received 23 February 2004

Accepted 20 June 2004 